\title{
INTELEKTUALIŚCI TOTALNI: MIĘDZY DOMINACJĄ A KRYTYKA
}

\author{
Tomasz Rawski \\ Krzysztof Świrek \\ Uniwersytet Warszawski
}

Jeszcze na początku XX wieku było jasne, że akt myślenia nie pokrywa się z efektem, który można formalnie zakwalifikować jako dzieło, a myślenia nie można do dzieła zredukować. Myślenie staje się tym, czym jest, dzięki swojemu rezultatowi dopiero w logice biurokratycznej, która potrzebuje zobiektywizowanego efektu do potwierdzenia samego istnienia procesu i jest obojętna na to wszystko, co w myśleniu nie przyjmuje formy możliwej do zobiektywizowania właśnie z biurokratycznego punktu widzenia. Razem z rozwojem dyskursu biurokratycznego coraz większego znaczenia dla nauki nabiera widmo specjalisty bez ducha $\mathrm{z}$ Weberowskiego opisu modernizacji - kogoś, kto do perfekcji opanował wąskie, technicznie zdefiniowane obszary ekspertyzy. Rozwój tej logiki, wówczas jeszcze nie wszechmocnej, pozwala właśnie Weberowi bardzo ostro postawić jej problem w określonym momencie historycznym pierwszych dekad XX wieku, a zarazem zarysować horyzont jej ekspansji, która z czasem zmieni samą definicję pracy intelektualnej. Specjalista zrazu potwierdza swoja biurokratycznie rozumianą użyteczność poprzez dostarczanie produktów będących technicznymi środkami do realizacji zewnętrznie (politycznie) zdefiniowanych celów. Logika biurokratyczna może jednak także rozszerzyć się na samą naukę, tym samym nie tylko zmuszając ją do udowadniania swojej użyteczności, ale wręcz czyniąc niewidzialnym wszelkie myślenie, które nie mieści się w zobiektywizowanych kryteriach. Wszelkie niewyspecjalizowane my- 
ślenie nieposiadające sobie przypisanego miejsca, które nie może legitymizować się użytecznymi efektami, staje się myśleniem niebyłym.

Rewersem tak rozumianego procesu byłaby figura uczonego, który przekracza wąskie ramy specjalizacji i wbrew logice biurokratycznej autonomicznie wyznacza sobie ramy działania. Tak rozumiana figure proponujemy w tym numerze nazwać intelektualista totalnym ${ }^{1}$ - uczonym przekraczającym ramy specjalizacji, uprawiającym swoje myślenie w sposób wielogatunkowy, nierzadko płynnie łączącym działalność naukowa z zaangażowaniem społecznym i politycznym. Intelektualista totalny to ktoś, kto wykracza poza standard uprawiania nauki w swoim środowisku i przełamuje wzorce kariery naukowej swojego czasu. To postać, której myślenie nie mieści się w wąskich ramach wyspecjalizowanej dyscypliny i szuka ujścia w gatunkach „nieczystych”, takich jak esej, wspomnienie, a nawet formy literackie.

Autorom, których teksty zostały pomieszczone w tym zbiorze, zaproponowaliśmy dwa konteksty teoretyczne. Pierwszym z nich jest intelektualista totalny jako postać dominująca w polu produkcji intelektualnej. W krytycznej analizie tej figury dokonanej przez Pierre'a Bourdieu (na przykładzie Jeana-Paula Sartre’a) intelektualista totalny to ktoś, kto osiaga dominująca pozycję w polu dzięki sprawnemu przemieszczaniu się pomiędzy rożnymi subpolami pola intelektualnego i kto sprawnie dokonuje transferu kapitałów pomiędzy różnymi sferami, skupiając „,w jednej osobie zespół władz intelektualnych oraz społecznych” (Bourdieu 2007: 321). Kluczowe dla Bourdieu jest to, co nazywa on ,zmysłem gry”, oraz wymiar biegłości w maksymalizowaniu kapitałów. Do bycia intelektualistą totalnym nie wystarcza sama chęć czy subiektywnie rozumiane powołanie. Decydująca jest możliwość osiagania zobiektywizowanej społecznym uznaniem przewagi - dlatego choćby, jak zauważa Bourdieu, biegły w profesjonalnym języku filozoficznym Sartre może przemieszczać się między polem naukowym a literackim, podczas gdy Albert Camus nie jest w stanie potwierdzić swojej totalnej pozycji, gdyż „demaskuje się” w swoich esejach filozoficznych jako dyletant (tamże: 323). Figura analizowana przez Bourdieu jest ściśle związana z uwarunkowaniami biograficznymi i pokoleniowymi, a także z rola środowiska, które jest władne, choćby nieformalnie, sankcjonować czyjąś pozycję w polu.

Bourdieu jest zainteresowany wymiarem dominacji, dlatego jego koncepcja znakomicie pasuje do analizowanej przezeń postaci Jeana-Paula Sar-

\footnotetext{
${ }^{1}$ Sam termin pojawia się u Pierre’a Bourdieu w miejscu, na które powołujemy się niżej, proponujemy jednak zmodyfikować znaczenie tego terminu, co staje się jasne w toku czytania tekstu.
} 
tre’a i daje się uogólnić na te postaci, których oddziaływanie w środowisku intelektualnym sumowało się w postać „,większą niż samo życie”, których oddziaływanie i wpływ nie redukuje się do wąsko rozumianych osiągnięć naukowych, czyli postaci autorytetów, mistrzów, „sumień środowiska” (w przypadku polskiej socjologii na myśl przychodzą postaci Stefana Czarnowskiego czy Jana Strzeleckiego). Osoby te zajmowały swoja pozycję dzięki łączeniu rzetelności naukowej, często przyjmującej raczej postać inspirującej erudycji niż specjalistycznej drobiazgowości, z „szerszym spojrzeniem" charakterystycznym dla profesji pisarza i etosem odpowiedzialności za życie publiczne. Nie mieszczą się zaś w tej koncepcji te postaci, którym brak intelektualnej pokory i formalna bezdomność uprawianych gatunków gwarantowały zainteresowanie, ale nie dominację - figury Stanisława Brzozowskiego czy Waltera Benjamina, a więc myślicieli, których legenda wyraźnie czerpie z motywów marginalności i prześladowania.

Inny wymiar teoretyczny otwiera się, jeśli skierować się w stronę formalnych aspektów totalności pracy intelektualnej. Wtedy kluczowa stanie się nie dominacja w polu, ale opór wobec specjalizacji i urzeczowienia pracy intelektualnej jako historycznego procesu zmieniającego charakter pracy w ogóle, a także warunki możliwości pracy intelektualnej w ramach kapitalistycznej formacji społecznej. Dla takiego ujęcia podstawą może być klasyczna konceptualizacja różnych aspektów procesu urzeczowienia dokonana przez Györgya Lukácsa, a także jego krytyczne rozumienie postulatu totalności w pracy Historia $i$ świadomość klasowa (1988). Urzeczowienie i specjalizacja łączą się ze sobą. Wydzielanie wąskich specjalności ma związek z postępującym przekształcaniem myślenia w obiekt, który można projektować, oferować i sprzedawać. Tak rozumiany proces specjalizacji ma również swoje fazy i nierówne czasowości: w pewnych obszarach wiedzy i rejonach geograficznych przebiegał szybciej, w innych wolniej. Pewne dyscypliny wiedzy zostały przez niego objęte wcześniej, inne zaś dłużej mogły dawać „schronienie” osobom niechętnym zamykaniu myślenia w wąskich ramach metodologicznych (szczególnie dotyczy to nauk społecznych, które już u swoich narodzin bywały myślane jako dyscypliny obejmujące najszersze, najbardziej złożone procesy). Intelektualista totalny mógł stawiać opór procesowi specjalizacji lub być założycielem pewnych dyscyplin jako uciekinier z innych (jak Florian Znaniecki, który porzucił projekty filozoficzne dla pracy w obszarze dopiero wypracowującej swoje narzędzia socjologii). Innym przykładem moga być figury genialnych innowatorów, którzy stawiali jawny opór podziałom dyscyplinarnym (jak Edward Abramowski, wrogi rygorowi intelektualnemu, który separował- 
by myśliciela od zmiennej rzeczywistości). Bezpośrednio z zagadnieniem specjalizacji będzie łączył się problem totalności, w koncepcji Lukácsa wypływający z marksistowskich postulatów ujmowania procesu historycznego jako konfliktowej całości: część (obiekt estetyczny, praktyka kulturowa, nawet zachowanie) uzyskuje swój „sens” dopiero z perspektywy swojego umiejscowienia w ramach procesu historycznego, ujmowanego jako walka klas. Tak rozumiana „całość” jest bliska założeniom krytycznych nauk społecznych, dla których do dziś ukazywanie społecznych uwarunkowań jest podstawową formą demaskacji.

\section{/// Dialektyka urzeczowienia}

Tak rozumiana postać intelektualisty totalnego jest uwikłana w specyficzna dialektykę, którą można ujmować jako ściśle powiązaną z nowoczesnością. Konceptualizują to na różne sposoby dwa teksty zamieszczone w pierwszej części zbioru. Krzysztof Świrek rekonstruuje problematykę fetyszyzmu towarowego i urzeczowienia: w tym kontekście praca intelektualna jest traktowana jako rzeczywistość poddana tym samym historycznym procesom, co całość życia społecznego. Intelektualiści totalni stają się kategorią jakoś wydzielona i charakterystyczna dopiero w opozycji do procesu urzeczowienia i w jego kontekście, to znaczy na tle generalnych tendencji opanowujących sferę pracy intelektualnej na równi z innymi sferami działalności społecznej.

Z tej perspektywy widać również, na czym polega specyfika totalności jako figury oporu - niekoniecznie jest ona tym samym, co społeczne i polityczne zaangażowanie, chociaż go nie wyklucza. Intelektualista totalny jest krytyczny wobec procesów zachodzących w rzeczywistości na szczególny, to znaczy formalny sposób. To forma jego pracy: nietypowa gatunkowo, trudna do zakwalifikowania administracyjnie, niejasno odnosząca się do specjalizacji i norm fachowości (jeśli nie: jawnie się im przeciwstawiająca) staje się punktem oporu.

Zaznacza się od razu także pewien limit czy ograniczenie tej strategii jako strategia opozycyjna może ona sytuować intelektualistę i jego pracę na marginesie kluczowych procesów. Jest to wyraźnie widoczne w sposobie, w jaki funkcjonuje refleksja wielu spośród klasycznych intelektualistów totalnych: przemieszcza się ona właśnie z marginesów do centrum, spotyka się często z recepcją opóźniona, przesunięta, np. lokującą danego twórcę w różnych dyscyplinach równocześnie. Szczególnie wyraźne jest to w przypadku tych spośród intelektualistów totalnych, którzy swoją uwagę poświę- 
cali refleksji politycznej: ich myśl krytyczna jest często niewspółmiernie istotniejsza niż jakiekolwiek pozytywne wnioski strategiczne czy organizacyjne, za bardzo odstające od pragmatycznego wymiaru walki politycznej. Z tej perspektywy intelektualista totalny jawi się jako postać skazana na marginalność, jego wysiłek krytyczny - skazany na rolę znaczącego gestu, bezradnego wobec generalnych procesów, którym się przeciwstawia.

Pytanie o rodzaj działania, które można przypisać dyskursowi intelektualnemu, podejmuje tekst Stanisława Chankowskiego. Autor opisuje problematykę klasy intelektualnej w myśli politycznej G.W.F. Hegla, wskazując na niejasny status intelektualistów w nowoczesnym państwie. $Z$ jednej strony, są oni niezbędni do jego funkcjonowania i taki właśnie, funkcjonalny charakter tej grupy da się wyprowadzić z pewnych Heglowskich sformułowań. Z drugiej strony, ich oddziaływanie nie daje się zredukować do żadnej pozytywnej wiedzy i w tym sensie nigdy nie da się sprowadzić do technicznie rozumianej funkcji. Intelektualiści zdają się odgrywać swoją rolę w nowoczesnym państwie nie tyle ze względu na ekspercka, pozytywną wiedzę, ile ze względu na swój wydzielony status, czy też, jak pisze autor tekstu, „symboliczny tytul”, który można rozumieć jako społeczny mandat do stania się żywą figurą refleksyjności społeczeństwa jako takiego. Intelektualiści byliby więc w świetle tego tekstu przede wszystkim tymi, którzy wiedzą - choć to, co wiedza, pozostaje niewypowiedziane do końca.

Ten właśnie sposób funkcjonowania intelektualistów totalnych - nie poprzez ekspercką wiedzę, ale przez symboliczny tytuł - Chankowski zestawia ze sposobem, w jaki w psychoanalizie lacanowskiej konceptualizowana jest pozycja psychoanalityka. Jako podmiot założonej wiedzy psychoanalityk jest nie tyle doradzającym ekspertem, ile kimś, kto ma rozumieć znaczenie cierpienia podmiotu, potrafi je zrekonstruować, niejako odczytując je jak zapomniany szyfr. Dla opisu relacji między psychoanalitykiem a analizantem (osobą przychodząca na analizę) kluczowy nie jest transfer wiedzy, ale relacja pragnienia: analizant pragnie się dowiedzieć i widzi w analityku kogoś, kto zna jego sekret. Proces analizy, jak nauczał Jacques Lacan, polega na wykorzystaniu tego pragnienia (zob. 1998: 235), a nie na nauczaniu podmiotu, jak ma rozumieć siebie i jak żyć.

Zdają się wypływać stąd specyficznie rozumiane etyczne zadania intelektualistów: w perspektywie tekstu Chankowskiego totalność jest nie tyle rzeczywistością (części) pracy intelektualnej, ile założeniem i zobowiązaniem, nieodłącznym od charakteryzującej nowoczesność ambicji budowania rozumnych relacji społecznych oraz instytucji gwarantujących minimum sprawiedliwości. Takie zadanie wymaga „lustra” w postaci osób 
zdolnych do interpretowania życia społecznego i rozpoznawania jego nieszczęść i niedomagań z pozycji krytyków. Ujęcia Świrka i Chankowskiego pokazują, że wartość pozycji intelektualisty nie leży w pozytywnych rozwiązaniach czy wiedzy eksperckiej, ale raczej w formalnych aspektach pracy intelektualistów i pozycjach przez nich zajmowanych, mieści się ona raczej w możliwości abstrahowania od technicznie rozumianych wymogów chwili, niż w dostarczaniu najlepszych rozwiązań.

\section{/// Totalności peryferyjne}

Kolejne trzy teksty odsłaniają specyfikę funkcjonowania intelektualistów totalnych w kontekście wschodnioeuropejskim, rozumianym jako peryferyjny (zob. Wallerstein 1974, 1976), czym skłaniaja do namysłu nad tym, w jakiej mierze propozycje teoretyczne rozwijane na gruncie zachodnim - takie jak francuska propozycja Pierre’a Bourdieu - daja się adekwatnie odnieść do społeczeństw (byłego) bloku wschodniego.

Na pierwszy rzut oka teksty te moga wydawać się luźno powiązane, ponieważ autorzy omawiają sylwetki przedstawicieli różnych pokoleń intelektualistów, którzy żyli i tworzyli w różnych kontekstach instytucjonalnych, a w dodatku szczyt działalności każdego z nich przypadł na odmienny moment historyczny. A jednak doświadczenia totalności charakterystyczne dla Lidii Ginzburg (pokolenie radzieckiej awangardy lat 20. XX wieku), Romana Zimanda (pokolenie polskiego stalinizmu lat 40. i 50.) i Ivana Lovrenovicia (pokolenie ukształtowane w dojrzałym jugosłowiańskim socjalizmie lat 70.) łączą dwie fundamentalne kwestie. Po pierwsze, chodzi o kwestię warunków strukturalnych, czyli zarówno o specyfikę konfiguracji całego systemu pól społecznych, jak i o kształt wzajemnych relacji między samymi polami. Po drugie, chodzi o specyfikę nowoczesnego procesu historycznego, którego te warunki są w dużej mierze produktem.

Patrząc przez pryzmat kwestii strukturalnych, każdy z trzech tekstów można czytać jako studium warunków możliwości funkcjonowania intelektualisty totalnego w takim systemie pól, który jest - jako całość - naznaczony silną dominacja pola politycznego i w którym granice wewnątrz pola produkcji intelektualnej, te między poszczególnymi przestrzeniami działalności intelektualnej (naukowa, publicystyczna, społecznie i politycznie zaangażowana) potrafią być nieostre, nawet zatarte. Jeśli natomiast spojrzeć na specyfikę procesu historycznego, każdy z tekstów warto widzieć w perspektywie wspólnego, a zarazem unikatowego dla kontekstów wschodnioeuropejskich doświadczenia radykalnych przetasowań w struk-

\section{/ 16 STANRZECZY 1[16]/2019}


turze społecznej-w tym w polu produkcji intelektualnej - będących efektami wielkich XX-wiecznych przełomów politycznych, od rewolucji październikowej 1917 roku po rozpad Jugosławii z połowy lat 90. XX wieku.

Wszystkie trzy studia wskazują, że - niezależnie czy w ZSRR/Rosji, Polsce czy Jugosławii/Bośni i Hercegowinie - pozycja przetargowa licznych intelektualistów totalnych w polu produkcji intelektualnej pozostawała i pozostaje zasadniczo słaba, niepewna i nieustannie zagrożona. Zwłaszcza teksty Katarzyny Roman-Rawskiej (Ginzburg) i Jana Olaszka (Zimand) dobrze pokazuja, jak ryzykowny może okazać się splot przemożnej skłonności wschodnioeuropejskich intelektualistów totalnych do całkowitego poświęcania się doniosłej sprawie z silną niechęcią i/lub niezdolnością do trwałego podporządkowania się dominującym siłom klasyfikacji i kategoryzacji. W dłuższym okresie totalność, która w dodatku odmawia uznania czyjegoś zwierzchnictwa nad sobą, z trudem odnajduje dla siebie względnie bezpieczną pozycję we wschodnioeuropejskich polach produkcji intelektualnej, a o podejmowaniu prób walki o pozycję dominująca nie warto nawet wspominać. Wszystkie trzy teksty pokazują więc, że intelektualiści totalni na peryferiach dużo rzadziej dysponują możliwościami wyboru stawek w grze, której są uczestnikami, zaś dużo częściej pozostają zmuszeni - jak Lidia Ginzburg - do intensywnego angażowania sił w nieustanna obronę swej twórczej niezależności w polu produkcji intelektualnej, czy jak Roman Zimand - do wycofania się w cień parasolowej instytucji (jaką był Instytut Badań Literackich PAN) i funkcjonowania na obrzeżach pola. Ten problem marginalizacji szczególnie wyraźnie ukazuje tekst Dominiki Kanieckiej o Ivanie Lovrenoviciu - intelektualiście totalnym z Jugosławii/ Bośni i Hercegowiny, przed którym zamknięte są wszelkie kanały instytucjonalnego uczestnictwa w tamtejszym polu akademickim.

Co istotne, warunki strukturalne pól wschodnioeuropejskich wydają się dwojako warunkować możliwości zdobycia i podtrzymania/obrony tych zdominowanych pozycji. Z jednej strony wzajemna przenikalność różnych przestrzeni działalności intelektualnej - tj. istnienie stosunkowo nieostrych granic między tymi przestrzeniami oraz tworzącymi je środowiskami - wydaje się oferować możliwości płynnego przechodzenia od jednego rodzaju twórczości intelektualnej do drugiego, co musi sprzyjać realizowaniu peryferyjnych totalności. W tym sensie Ginzburg, Zimand i Lovrenović dysponują siłą dwojakiego rodzaju, gdzie jedna z nich to siła szerokiego wachlarza służącego legitymizacji własnych pozycji, zaś druga - to siła podtrzymywania przy życiu tego rodzaju działalności intelektualnej, której całościowy charakter pozostaje nadrzędny wobec logiki drobia- 
zgowej kategoryzacji, fragmentacji i waskiego podziału dyscyplinarnego. Z drugiej strony, te same studia przypadków odsłaniają problemy związane z wzajemna przenikalnością i nieostrościa granic między subpolami, w tym jeden z najważniejszych, czyli brak wyrazistego zakorzenienia środowiskowego. To, że intelektualiści totalni nigdzie nie moga zagrzać miejsca na dobre, miewa różnorakie negatywne konsekwencje: od ciagłego poczucia obcości, nieustannego bycia „poza” (Lovrenović, Zimand), przez kłopoty z obroną własnej pozycji w razie ataku z zewnątrz, aż po intensywną walkę o utrzymanie spójności własnego projektu intelektualnego (Ginzburg, Lovrenović).

Wschodnioeuropejska specyfika procesu historycznego także wydaje się dwojako warunkować kontekst działalności intelektualistów totalnych. $\mathrm{Z}$ jednej strony nie ulega wątpliwości, że wielkie przetasowania strukturalne - przy całym tragizmie, który im towarzyszy - bywają momentami szerokiego otwarcia przestrzeni społecznej na nowych aktorów i nowe formuły działalności zbiorowej. Najlepiej wpisuje się w to przypadek Lidii Ginzburg, która zbudowała swa podmiotowość intelektualistki totalnej przede wszystkim na doświadczeniu bycia częścią rewolucyjnie nastrojonej radzieckiej awangardy lat 20. XX wieku. Złożoność tego doświadczenia świetnie widać też na przykładzie Zimanda, którego totalna podmiotowość wydawała się kształtować między początkowym, płomiennym zaangażowaniem w polski stalinizm a późniejszą postawą krytycznego indywidualizmu, silnie opozycyjną wobec władzy socjalistycznej. Z drugiej jednak strony, te same przetasowania strukturalne, które skutkuja wzmożoną niestabilnością pól i rozluźnieniem wewnętrznych reguł ich funkcjonowania, zwykły wywoływać zgoła przeciwne dążenie do stabilizacji pól wokół jasno zdefiniowanych kategorii i klasyfikacji, wśród których brakuje miejsca na totalność. Związanej z tym marginalizacji także doświadczyli wszyscy opisywani w bloku intelektualiści: Ginzburg najsilniej w okresie radzieckiego stalinizmu lat 30., Zimand - w latach 80., Lovrenović zaś - zwłaszcza po rozpadzie Jugosławii, w Bośni i Hercegowinie przełomu wieków XX i XXI.

Krótko mówiąc, teksty dotyczące totalności peryferyjnych wydają się odsłaniać takie uwarunkowania historyczno-strukturalne, które w niewielkim lub zgoła nikłym stopniu bywają teoretyzowane poza kontekstem wschodnioeuropejskim, a które jednocześnie wydaja się w sposób fundamentalny określać możliwości funkcjonowania tutejszych intelektualistów. Wschodnioeuropejska konfiguracja całego systemu pól okazuje się w dłuższym okresie skazywać intelektualistów totalnych na funkcjonowanie na 
drugim planie lub na obrzeżach pola produkcji intelektualnej - trend, który bywa, choć nie musi być zakłócany przez historyczną dynamikę wielkich przetasowań strukturalnych. Z kolei specyfika relacji między poszczególnymi subpolami w samym polu produkcji intelektualnej może czynić te obrzeża względnie bezpiecznym miejscem realizowania (się) peryferyjnych totalności.

\section{/// Między rewolucją a restauracją}

Wschodnioeuropejską logikę funkcjonowania pola produkcji intelektualnej - czyli taka, w której totalność jest silnie podatna na marginalizację, a jednocześnie słabo podatna na całkowite zniknięcie - dobrze uwydatnia zestawienie z tekstem otwierającym kolejny wątek tematyczny. Studium Iwony Młoźniak problematyzuje figurę intelektualisty totalnego we francuskim krajobrazie intelektualnym po 1968 roku, kładąc nacisk na szereg korzyści, jakie płyna z ciagłego przekraczania granic - nie tylko tych między dyscyplinami naukowymi, ale przede wszystkim tych między nauką a zaangażowaniem w sprawy społeczne - zarówno dla pojedynczych intelektualistów, jak i dla pola produkcji intelektualnej w ogólności. Na przykładzie strategii funkcjonowania dwóch intelektualistów w tym polu - Michela Foucaulta i Gillesa Deleuze'a - Młoźniak omawia zasadniczy paradoks ich działalności, który dobrze zdaje sprawę z adekwatności teoretycznej propozycji Bourdieu na gruncie francuskim. Paradoks polega na tym, że połączenie stanowiska otwarcie antyinstytucjonalnego wobec akademii i radykalnie krytycznego wobec głównego nurtu francuskiej filozofii z nieustannym przemieszczaniem się między poszczególnymi subpolami skutkuje złożona dialektyką uprawomocnienia, czyli nie tylko zwrotnie wzmacnia pozycję przetargową intelektualistów totalnych w każdym z tych pól, lecz także wzbogaca same pola, modyfikując rutyny ich funkcjonowania. Ten silny kontrast między doświadczeniem mocnej totalności (Foucault i Deleuze) z jednej strony a doświadczeniem totalności zmarginalizowanej (Ginzburg, Zimand i Lovrenović) z drugiej zdaje się potwierdzać istnienie zasadniczych różnic co do warunków możliwości oferowanych intelektualistom totalnym przez zachodnio- $i$ wschodnioeuropejskie pola produkcji intelektualnej.

Jednocześnie studium przypadków francuskich otwiera dyskusję dotyczącą kryzysu samej figury intelektualisty - czyli tę, która stanowi sedno drugiego bloku tematycznego. Rekonstruując sposoby, w jakie Foucault i Deleuze starają się zdetronizować figurę intelektualisty jako odrębnego 
bytu społecznego - w tym najważniejszą dla nich obu strategię multiplikacji/zwielokrotnienia autora - Młoźniak zauważa, że sposoby te nie zmierzają w kierunku całkowitego zanegowania społecznej roli intelektualisty. Dwaj francuscy filozofowie dążą przede wszystkim do takiego przeformułowania tej roli, by wkomponować w nią na stałe pierwiastek krytyczny. O ile dla Foucaulta ta rekonfiguracja polegałaby na ciagłym balansowaniu na linii oddzielającej reprodukcję władzy od jej krytyki - czyli na czymś w rodzaju wiecznej gry w berka prowadzonej przez intelektualistę z władza - o tyle Deleuze wydaje się działać niczym dywersant, pozornie wchodząc w tradycyjna rolę intelektualisty, ale tylko po to, by od środka przełamać rządzące nią reguły.

Bardziej radykalną diagnozę sytuacji stawia Jacek Zych, ogłaszając w swym tekście długo wyczekiwaną, jak sam twierdzi, śmierć intelektualisty. W utrzymanej w duchu marksowskim analizie przemian szkolnictwa wyższego w Polsce po 1989 roku autor przedstawia tę sferę jako przestrzeń ostrego konfliktu klasowego, w której współczesna, skonsolidowana burżuazja konsekwentnie osiaga coraz większą dominację nad zdziesiątkowanym proletariatem. Zarówno ta konstatacja, jak i wyłożone w tekście przekonanie o braku zasadniczych różnic między pracą intelektualną a pracą fizyczną skłaniają Zycha do tezy o konieczności odrzucenia tego podziału kategorialnego na rzecz dowartościowania pracy jako takiej, a co za tym idzie - do całkowitego zanegowania figury intelektualisty, która miałaby rozpłynąc się w dużo szerszej kategorii pracownika. Te analizy Zych łączy z inspirowanymi zwłaszcza myślą włoskich operaistów rozważaniami nad politycznym potencjałem tezy o śmierci intelektualisty, czyli nad możliwymi sposobami wykorzystania płynących z niej konsekwencji w takiej praktyce politycznej, która byłaby zorientowana na przełamywanie rosnącej dominacji burżuazji na gruncie akademickim. Co ciekawe, synkretyzm charakteryzujący tekst Zycha - który wypada usytuować na przecięciu radykalnej propozycji teoretycznej, odważnej analizy empirycznej i gatunku manifestu politycznego - powoduje, że można go odczytywać jako propozycję noszącą liczne znamiona totalności.

Pomiędzy analizowaną w tekście Iwony Młoźniak „historią sukcesu” Foucaulta i Deleuze’a, skutecznie rekonfigurujących pozycję filozofa w polu intelektualnym, a narracją nieuchronnej śmierci intelektualisty z tekstu Zycha można usytuować artykuł Jana Kozubowskiego. Autor przygląda się koncepcji „warstwy względnie oderwanej” z prac klasyka socjologii wiedzy Karla Mannheima. W artykule tym wybrzmiewają liczne tematy, obecne także w innych tekstach zbioru: kwestia roli pracy intelektualnej 
„w” i „dla” nowoczesności, usytuowania intelektualistów i ich względnej, często mającej zaledwie charakter postulatu neutralności w walkach społecznych, a także totalności jako krytycznego oglądu całości sytuacji społecznej. „Względność” i „,relatywność” jest leitmotivem tego tekstu: intelektualiści zajmuja pozycję ponad walkami społecznymi jedynie „w jakimś aspekcie” i warunkowo, a ich praca „totalizacji”, chociaż zgłasza roszczenia do obiektywności, to ostatecznie bliższa jest pogłębionej refleksyjności. Rozważania nad dylematami ujęcia Mannheimowskiego prowadzą autora tekstu w stronę kategorii obcości w ujęciu zaproponowanym przez Georga Simmla: w ten sposób obiektywność intelektualisty staje się raczej refleksyjnym wyobcowaniem z walk społecznych. W tekście Kozubowskiego intelektualista nie jawi się ani jako skuteczny gracz walk o dominację w polu, ani jako postać schyłkowa - w pewnym sensie staje się kimś skazanym na „odgrywanie” w swojej własnej pozycji sprzeczności i impasów charakterystycznych dla samej nowoczesności: uroszczeń rozumu i jego ciągle unieważniającej, samopodważającej krytyki; ambicji zmiany świata społecznego i jej bezsilnego, zdystansowanego opisu.

\section{/// Nowe początki}

Ostatnie trzy teksty w największym stopniu zakorzenione są w historii myśli społecznej, problematyzują bowiem trzech intelektualistów totalnych przełomu XIX i XX wieku - Edmunda Husserla, Edwarda Abramowskiego i Georga Simmla - jako architektów odważnych, dalekosiężnych przedsięwzięć myślowych obliczonych na radykalną metamorfozę zastanej rzeczywistości. Fundamentalna zbieżność między tymi trzema propozycjami polega na tym, że każda z nich była pomyślana jako kompleksowa odpowiedź na konkretne kryzysy wpisane w ideę nowoczesności. O ile jednak odpowiedzi Husserla i Abramowskiego ufundowane były przede wszystkim na radykalnym geście unieważnienia zastanej rzeczywistości, o tyle dla Simmla kluczowy zdaje się raczej gest częściowego wykraczania poza nią.

W studium otwierającym ten zestaw tekstów Marek Pokropski i Jacek Migasiński rozpatrują Husserlowską fenomenologię jako projekt całościowej odnowy filozofii, którego rolą byłoby przezwyciężenie europejskiego kryzysu racjonalności, a co za tym idzie - kryzysu całej nowoczesnej nauki. Totalność Husserla autorzy odnajdują w radykalizmie i maksymalizmie projektu fenomenologicznego, a precyzyjnie rzecz ujmując - w jego dążeniu do odrzucenia całego dotychczasowego dorobku filozoficznego i położenia fundamentów pod zupełnie nowy gmach nowoczesnej nauki, która 
umożliwiałaby ludzkości dażenie do jedności świata w oparciu o świadomy, uniwersalny rozum. Husserl jawi się więc u Pokropskiego i Migasińskiego w dużej mierze jako totalny racjonalista, jego projekt zaś - jako ostrze wymierzone w ,pozytywistyczne zawężenie idei nauki”, czyli w zbiór redukcjonizmów dyscyplinarnych, które usiłują wykluczyć możliwość zadawania pytań o sens i istotę racjonalności, samego zaś człowieka próbują sprowadzić do zbioru faktów przyrodniczych lub historycznych. W tym sensie przypadek Husserla - intelektualisty programowo apolitycznego, skoncentrowanego na odnowie nauki jako takiej - ciekawie koresponduje z problematyką poruszaną w bloku poprzednim. Pokazuje on bowiem, że totalność nie musi uobecniać się na przecięciu kilku pól działalności intelektualnej, lecz może z powodzeniem realizować się w dążeniu do całościowej metamorfozy jednego pola.

Kolejny gest unieważnienia przedstawia Andrzej Waśkiewicz, omawiając wizję ładu stowarzyszeniowego Edwarda Abramowskiego - projekt, który miał być lewicową odpowiedzią na rosnąca w Europie dominację dwóch zasadniczo sprzyjających sobie sił: kapitalizmu i nowoczesnego państwa. Z ducha anarchosyndykalistyczną propozycję Abramowskiego gdzie porządek społeczny jawi się jako równościowy ład wyłaniający się w ramach żywiołowej oddolnej aktywności ludzkiej opartej na zasadzie współpracy i Arystotelesowskiej przyjaźni ze względu na korzyść - sytuuje Waśkiewicz w nurcie utopii akapitalistycznych. I właśnie w specyfice tego nurtu wydaje się tkwić istota totalności takich intelektualistów jak Abramowski. Otóż stojący u jej podstaw radykalny gest unieważnienia zastanej rzeczywistości nie polega - jak u Husserla - na konfrontacji z tą rzeczywistością poprzez jej zanegowanie, lecz na równoległym budowaniu całościowej alternatywy - zrębów nowego porządku społecznego wyposażonego w jakości, które miałyby zadecydować o jego przyszłym zwycięstwie nad dotychczasowym ładem kapitalistyczno-państwowym. W tym sensie totalność Abramowskiego ma charakter fundamentalny, lecz nie fundamentalistyczny. Ponadto utopijny projekt będący tej totalności wyrazem wydaje się jednak odznaczać trzeźwym realizmem, ponieważ u jego podstaw stoi przekonanie o kluczowej roli logiki efektywności gospodarczej dla nowego ładu społecznego.

Zupełnie inaczej rzecz ma się z totalnością Georga Simmla, która problematyzuje tekst Dariusza Brzezińskiego. Nie jawi się ona jako totalność demiurga, który chce stworzyć nowy porządek - czy to naukowy (Husserl) czy społeczny (Abramowski) - od samych podstaw, ale raczej jako totalność poszukiwacza szczelin w zastanym porządku, przez które możliwe 
byłoby wyjrzenie na zewnątrz niego, dostrzeżenie nowych obszarów refleksji naukowej i wytyczenie ku nim nowych ścieżek. W tym sensie totalność Simmla jest fundowana przez powtarzany wciąż od nowa gest częściowego wykraczania poza to, co dane: poza granice dyscyplin naukowych, poza klasyczną formę stylu naukowego, wreszcie - poza stosunkowo wąski krąg odbiorców twórczości akademickiej. Inaczej mówiąc, totalność propozycji Simmla realizowałaby się nie tyle poprzez próbę zastapienia zastanego porządku innym, ile raczej poprzez wysiłek ciagłego przeciwdziałania procesowi zastygania tego porządku. W tekście Brzezińskiego Simmel jawi się więc jako niestrudzony odkrywca nowych obszarów badawczych, którego analizy - choć fragmentaryczne i zupełnie nieaspirujące do głębszej spójności teoretycznej - bez wątpienia miały charakter pionierski. Ta ostatnia kwestia łączy zresztą wszystkich trzech myślicieli prezentowanych w ostatnim bloku. Husserl, Abramowski i Simmel są mianowicie przykładami na to, że intelektualista totalny nierzadko bywa prekursorem zupełnie nowych sposobów myślenia o rzeczywistości społecznej - takich, które wcześniej wydawały się nie do pomyślenia.

\section{/// Podsumowanie}

Prezentowane w poszczególnych tekstach refleksje oferuja dwa generalne punkty widzenia, od których trudno uciec w myśleniu o intelektualistach totalnych: jeden $\mathrm{z}$ nich rozpatruje problem totalności i pozycji intelektualistów z perspektywy ogólnej i pojęciowej, wpisując tę figurę $w$ mapę klasycznych pytań związanych $z$ teoriami nowoczesności i socjologią wiedzy. Drugi punkt widzenia wychodzi od poszczególnych strategii i biografii, ponieważ właśnie bez konkretu biograficznego i rozmowy o konfiguracjach pracy intelektualnej nie sposób omawianej w tych tekstach figury napełnić treścią. Tak właśnie teksty te przyczyniaja się do wypełnienia roli tego zbioru: wskazuja kierunek dalszych badań i zachęcają do wyjrzenia poza współczesne definicje (i impasy) pracy intelektualnej.

Na sam koniec warto zwrócić uwagę na znaczenie niniejszego numeru dla namysłu nad aktualna kondycją nauki w Polsce. Ostatnia reforma nauki i szkolnictwa wyższego miała przedefiniować pracę intelektualną, orientując ją silniej na międzynarodową konkurencję, a środki wydawane na naukę powiązać ściślej z normami ekonomicznej efektywności. Logika stojąca za reformą opisuje naukę jako sferę bezwzględnej konkurencji o uznanie środowiskowe i zasoby na badania, w której to sferze nie ma miejsca dla 
przegranych. Efekt Mateusza² jest wpisany w tę logikę jako zasada, którą trzeba afirmować, chociaż założenie o jej zbawiennym działaniu w nauce jest co najmniej wątpliwe. Wykracza to dalece poza ogólne założenia o funkcjonalności jakichkolwiek hierarchii czy stratyfikacji: to prawda, że nauka zawsze była domeną rywalizacji o prawdę i zawsze prowadziła do ustanawiania pewnych hierarchii, jednak takie ogólne założenia nie moga sankcjonować skrajnych nierówności sprowadzających świat naukowy do wąkiej elity gwiazd i masy prekarnych badaczy pracujących „od projektu do projektu". W wizji, w której nie ma już miejsca na naukę pojmowana jako dobro wspólne, znika kooperacja, zostaje jedynie rywalizacyjna orientacja na indywidualny sukces, mierzony liczbą „prestiżowych” publikacji i wysokością pozyskanych środków pieniężnych. Znika też możliwość rozumienia nauki w sposób autonomiczny wobec rywalizacyjnej gry o zasoby i uznanie, potwierdzone zobiektywizowanymi wskaźnikami, uznawanymi w ramach administracyjnych standardów. W tak rozumianym systemie brakuje „luk”, w których dałoby się nadal uprawiać myśl niepasującą do wąsko zdefiniowanych, profesjonalnych standardów. Innymi słowy, możemy zastanawiać się, ile arcydzieł myśli społecznej nie mogłoby się ukazać, gdyby ich autorzy „wypadali z systemu” w ramach brutalnej walki konkurencyjnej już na początku swojej naukowej drogi. Tym ważniejsza staje się refleksja nad praca intelektualną rozumianą w innej logice. Jej również mogą służyć pomieszczone w tym zbiorze teksty.

Bibliografia:

/// Bourdieu P. 2007. Reguly sætuki. Geneza i struktura pola literackiego, tłum. A. Zawadzki, Universitas.

/// Lacan J. 1998. Four Fundamental Concepts of Psychoanalysis, tłum. A. Sheridan, W.W. Norton \& Co.

/// Lukács G. 1988. Historia i świadomość klasowa. Studia o marksistowskiej dialektyce, tłum. M.J. Siemek, PWN.

/// Wallerstein I. 1974. The Modern World System, Academic Press.

/// Wallerstein I. 1976. Semi-Peripheral Countries and the Contemporary World Crisis, „Theory and Society”, nr 3, s. 461-483.

${ }^{2}$ Mt 13,12: „Bo kto ma, temu będzie dodane, i nadmiar mieć będzie; kto zaś nie ma, temu zabiora również to, co ma” (wg Biblii Tysiąclecia). 